\title{
Stimulation by Alcohols of Cyclic AMP Metabolism in Human Leukocytes
}

\author{
POSSIBLE ROLE OF CYCLIC AMP IN THE ANTI-INFLAMMATORY \\ EFFECTS OF ETHANOL
}

John P. Atkinson, Timothy J. Sullivan, James P. Kelly, and Charles W. Parker

From the Departments of Medicine and Surgery, Washington University Medical School, St. Louis, Missouri 63110

\begin{abstract}
A B S T R A C T In this study ethanol and certain other short-chain aryl (benzyl and phenethyl) and aliphatic (methyl, propyl, butyl, and amyl) alcohols produced up to 10-fold increases in cyclic AMP (cAMP) concentrations in purified human peripheral blood lymphocytes. Ethanol concentrations as low as $80 \mathrm{mg} / \mathrm{dl}$ produced significant elevations in lymphocyte cAMP. Significant but less marked augmentation of cAMP in response to alcohols was observed in human platelets, human granulocytes, and rabbit alveolar macrophages. The mechanism of the alcohol-induced cAMP accumulation is probably secondary to membrane perturbation and consequent activation of adenylate cyclase, because ethanol directly stimulated this enzyme in lymphocyte membrane preparations but had no effect on lymphocyte phosphodiesterase activity.

Lysosomal enzyme release, by phagocytosing human leukocytes, and aminoisobutyric acid transport in mitogen-stimulated human lymphocytes were shown to be inhibited by ethanol and other alcohols at concentrations which also elevate cAMP. In general, the magnitude of the inhibition of these inflammatory processes correlated with the ability of the alcohol to elevate cAMP concentrations. Lectinand anti-thymocyte globulin-induced lymphocyte
\end{abstract}

This work was presented in part at the National Meeting of the American Federation for Clinical Research, Atlantic City, N. J., 2 May 1976 and published in abstract form. 1976. Clin. Res. 24: 324A. (Abstr.)

Dr. Atkinson is an Investigator, Howard Hughes Medical Institute. Dr. Sullivan is recipient of Allergic Disease Academic Award AI 00190-01 from the U. S. Public Health Service.

Received for publication 17 December 1976 and in revised form 31 March 1977. mitogenesis was inhibited or unaffected depending upon both the concentration and type of mitogenic stimulus and the concentration and type of alcohol utilized. Inflammatory mediator release from rat mast cells also was inhibited by ethanol and certain other alcohols, but whole cell cAMP was not increased. Ethanol may alter these inflammatory responses and other biologic processes at least in part by modulating cellular levels of cAMP.

\section{INTRODUCTION}

Cyclic AMP (cAMP)' has been considered to have a general anti-inflammatory action based on the ability of exogenously added cAMP or pharmacologic agents which elevate cAMP to inhibit chemotaxis, lysosomal enzyme release, histamine release, mitogenesis, and lymphocyte-mediated cytotoxicity $(1,2)$. We recently observed that heparin preparations containing benzyl alcohol as a preservative produced a severalfold elevation in cAMP concentrations in lymphocytes and smaller increases in platelets, polymorphonuclear leukocytes (PMNL), and alveolar macrophages (3). We subsequently demonstrated that benzyl alcohol was responsible for the increased cAMP levels (3). Short-chain aliphatic alcohols including ethanol have previously been reported to elevate cAMP in the thyroid, brain, intestine, liver, and pancreas apparently

\footnotetext{
${ }^{1}$ Abbreviations used in this paper: AIB, aminoisobutyric acid; cAMP, cyclic AMP; cGMP, cyclic GMP; Con A, concanavalin A; E-PHA, erythroagglutinating phytohemagglutinin; PBS, phosphate-buffered saline; PDE, phosphodiesterase; $\mathrm{PGE}_{1}$, prostaglandin $\mathrm{E}_{1}$; $\mathrm{PMNL}$, polymorphonuclear leukocytes; Z-NHS, zymosan treated for $30 \mathrm{~min}$ at $37^{\circ} \mathrm{C}$ with human $\mathrm{AB}^{+}$serum.
} 
through a stimulatory effect on adenylate cyclase (4-9), suggesting that cAMP may be involved in ethanol's action in a variety of tissues.

Excessive ingestion of ethanol has also been shown to be associated with an increased frequency and severity of infections both in human beings and experimental animals (10-12). A variety of pathophysiologic abnormalities undoubtedly contribute to this increased susceptibility to infection including alterations of hepatic, hematologic, and neurologic function. The possibility of direct anti-inflammatory effects of ethanol has received relatively little attention, although recently acute ethanol ingestion has been reported to impair leukocyte chemotaxis and adherence and mitogen-induced lymphocyte transformation (12-16).

The present report describes the results of experiments in human lymphocytes, neutrophils, and platelets, rabbit alveolar macrophages, and rat peritoneal mast cells that indicate several ways in which ethanol might inhibit the inflammatory response. In addition, we have documented the ability of alcohols to augment cAMP concentrations and studied the question of whether the effect of ethanol might be secondary to changes in intracellular cAMP.

\section{METHODS}

Materials. Reagent grade chemicals were used throughout. The source and method of preparation of solutions of theophylline, beef heart phosphodiesterase (PDE), prostaglandin $\mathrm{E}_{1}\left(\mathrm{PGE}_{1}\right)$, epinephrine, L-propranolol, $\left[{ }^{3} \mathrm{H}\right] \mathrm{CAMP}$, concanavalin A (Con A), and erythroagglutinating phytohemagglutinin (E-PHA) have been described (3, 17-20). The horse anti-human thymocyte globulin was a gift of Dr. William J. Wechter, The Upjohn Co., Kalamazoo, Mich. Absolute ethanol (U. S. Industrial Chemical Co. Div. of National Distillers and Chemical Corp., New York) and 95\% ethanol (Fisher Scientific Co., Pittsburgh, Pa.) were evaluated and found to produce similar results. Absolute ethanol was employed in most of the experiments. Phenethyl alcohol was purchased from Eastman Kodak, Co., Rochester, N. Y., and the other alcohols were obtained from Fisher Scientific.

Cell purification. Purified lymphocytes (92-98\% of the nucleated cells, recovery $50-75 \%, 20-30 \%$ B lymphocytes as determined by Ig staining) were obtained from dextransedimented mixed human peripheral blood leukocytes by Ficoll-Hypaque (Pharmacia Fine Chemicals, Inc., Div. of Pharmacia, Inc., Piscataway, N. J.) density gradient centrifugation as previously described (19-21). Preparations usually contained less than one erythrocyte and one platelet per nucleated cell. In some experiments, this preparation was further purified ( $>90 \%$ thymocyte-derived (T) lymphocytes as determined by E-rosettes and Ig staining) by filtration through a nylon wool column which removes granulocytes, monocytes, and most bone marrow-derived (B) lymphocytes $(21,22)$. Purified human neutrophils $(>98 \%$ of the total nucleated cells) were harvested from the Ficoll-Hypaque cell pellet as a by-product of the lymphocyte purification procedure (23) and subsequently handled like the lymphocyte preparations. Contaminating erythrocytes in the neutrophil preparations were removed either by hypoosmotic lysis (a 30-s exposure to $0.05 \mathrm{M} \mathrm{NaCl}$ ) or by gravity sedimentation in $6.0 \%$ (wt:vol) dextran. Human platelets were isolated using the method of Baenziger and Majerus (24). Rabbit alveolar macrophages of $>92 \%$ purity were harvested via methods previously reported (25). Rat peritoneal mast cells were obtained as described in previous reports from this laboratory (26). As determined by the ability to exclude trypan blue dye, all of the above cell populations were $>95 \%$ viable.

Experimental design for whole cell experiments. Human lymphocytes and granulocytes and rabbit alveolar macrophages were suspended in Hanks' balanced salt solution, usually at a cell density of $12.5 \times 10^{6} / \mathrm{ml}$, preincubated for $10 \mathrm{~min}$ at $37^{\circ} \mathrm{C}$, and distributed in $0.4-$ or $0.45-\mathrm{ml}$ aliquots among glass test tubes $(13 \times 100-\mathrm{mm})$ containing 0.05 or $0.10 \mathrm{ml}$ of the alcohol under study diluted in distilled water $\left(\mathrm{H}_{2} \mathrm{O}\right)$. In selected experiments, similar results were obtained if ethanol was diluted in Hanks' balanced salt solution. Human platelets were usually studied at a cell density of $1 \times 10^{9} / \mathrm{ml}$. The incubations were allowed to proceed for variable lengths of time at $37^{\circ} \mathrm{C}$. The cells were gently agitated initially and every 3 or $4 \mathrm{~min}$ thereafter. All studies were performed in triplicate, employing a single donor's cells prepared the day of the experiment. Multiple sets of controls (cells in Hanks' balanced salt solution containing 10 or $20 \% \mathrm{H}_{2} \mathrm{O}$ ) were included in each experiment. Unless stated otherwise, the reaction was stopped by centrifugation $(2,200 \mathrm{~g}$ for $2 \mathrm{~min})$ followed by freezing of the cell pellet in an ethanol-dry ice bath.

Cyclic nucleotide assay. In most experiments the cyclic nucleotides were extracted from cells by boiling and sonicating and CAMP and CGMP were measured by radioimmunoassay as previously described $(27-29)$. For comparative and confirmative purposes, in selected experiments cyclic nucleotides were purified before assay by perchloric acid protein precipitation, heating to $85^{\circ} \mathrm{C}$ for $3 \mathrm{~min}$, and ion-exchange column chromatography $(20)$. In the concentrations employed in these studies, the various alcohols used had no effect if added directly or if processed as in the absence of cells (i.e. buffer and alcohol) on the cAMP radioimmunoassay.

Confirmation of the alcohol-induced product as cAMP. In selected experiments, trace quantities of $\left[{ }^{3} \mathrm{H}\right] \mathrm{cAMP}$ and extracts from control lymphocytes and lymphocytes stimulated with $\mathrm{PGE}_{1}$ or one of the alcohols were incubated for various time periods at $37^{\circ} \mathrm{C}$ with a high concentration of partially purified beef heart cyclic nucleotide PDE and 10 $\mathrm{mM} \mathrm{Mg}^{2+}$ and then boiled, adjusted to $\mathrm{pH} 6.2$ with sodium acetate buffer $(0.05 \mathrm{M})$, and then analyzed for residual activity in the cAMP immunoassay. These same extracts were also examined for migratory behavior (characteristic of (AMP) in a thin-layer chromatography system before and after PDE treatment (3).

PDE activity. Ficoll-Hypaque-purified lymphocytes $\left(50\right.$ or $\left.100 \times 10^{6} / \mathrm{ml}\right)$ maintained at $4^{\circ} \mathrm{C}$ were sonicated for $60 \mathrm{~s}(6-10$-s bursts) and centrifuged at $16,000 \mathrm{~g}$ for $15 \mathrm{~min}$ at $4^{\circ} \mathrm{C}$. cAMP PDE activity in the supernate was measured by using a previously reported modification of established methods (30). As with most other cell types which have been studied, low and high $K_{m}$ PDE activities are present in human peripheral blood lymphocytes (31).

Assay of adenylate cyclase activity. Adenylate cyclase activity in broken lymphocyte cell preparations was measured utilizing previously published modifications of established methods $(32,33)$.

Lymphocyte blastogenesis. Lymphocyte blastogenesis was examined using a minor modification of methods previously described from our laboratory $(18,20,23)$. Ficoll- 
Hypaque-purified lymphocytes were suspended in RPMI 1640 containing $10 \%$ heat-inactivated fetal calf serum, penicillin $100 \mathrm{U} / \mathrm{ml}$, and streptomycin $100 \mu \mathrm{g} / \mathrm{ml}$ at a final lymphocyte concentration of $6.25 \times 10^{5}$ cells $/ \mathrm{ml}$. 160- $\mu \mathrm{l}$ aliquots of the cell suspension were added to individual wells in microtiter II plates (Falcon Plastics, Div. of BioQuest, Oxnard, Calif.) containing $40 \mu \mathrm{l}$ of phosphate-buffered saline (PBS) or mitogen to a final volume of $200 \mu \mathrm{l}$. Alcohols were diluted to the appropriate volume in $\mathrm{PBS}(0.15 \mathrm{M} \mathrm{NaCl}$, $0.01 \mathrm{M} \mathrm{PO}-, \mathrm{pH} 7.4$ ) on the day of the experiment. In experiments attempting to demonstrate effects of alcohols on mitogenesis, $140 \mu \mathrm{l}$ of the cell suspension and $60 \mu \mathrm{l}$ of the mitogen, buffer, or mitogen and alcohol, together and separately, were used except where otherwise specified. The cell cultures were incubated in $95 \% \mathrm{O}_{2}-5 \% \mathrm{CO}_{2}$ for 48 or $72 \mathrm{~h} ; 1.0 \mu \mathrm{Ci}\left(5 \mathrm{mCi} / 5 \mathrm{~cm}^{3}\right.$ sterile PBS diluted $\left.1: 10\right)$ of $\left[{ }^{3} \mathrm{H}\right]$ thymidine (Amersham/Searle Corp., Arlington Heights, Ill.) was added $5 \mathrm{~h}$ before harvesting. Cells were harvested using a multiple cell harvester (ADAPS Inc., Dedham, Mass.); radioactivity precipitated by trichloroacetic acid was measured by liquid scintillation counting employing a liquid scintillation counter. All cultures were performed in triplicate or sextuplicate.

Aminoisobutyric acid (AIB) transport. AIB transport was examined utilizing $\left[{ }^{14} \mathrm{C}\right] \mathrm{AIB}$ by methods previously reported from this laboratory (23). The various alcohols or PBS were added to glass tubes in a total volume of $0.1 \mathrm{ml} ; 0.4 \mathrm{ml}$ of a lymphocyte cell suspension $\left(12.5 \times 10^{6}\right.$ cells $/ \mathrm{ml}$ minimum essential medium $+2 \%$ (vol:vol) heated AB serum, pH 7.4) was added to each tube. The cells were incubated for 30$240 \mathrm{~min}$ at $37^{\circ} \mathrm{C}$ in a $95 \% \mathrm{O}_{2}-5 \% \mathrm{CO}_{2}$ atmosphere and pulsed for $30 \mathrm{~min}$ with [ ${ }^{14} \mathrm{C}$ ]AIB $(0.5 \mu \mathrm{Ci} /$ tube, $0.2 \mathrm{mM} \mathrm{AIB}$, final concentration). The incubation was terminated by addition of $2 \mathrm{ml}$ of ice-cold PBS containing unlabeled AIB (AIB-PBS, $0.15 \mathrm{M} \mathrm{NaCl}, 0.01 \mathrm{M} \mathrm{PO}_{4}^{-}, 0.01 \mathrm{M} \mathrm{AIB}, \mathrm{pH}$ 7.4). The cells were centrifuged at $1,200 \mathrm{~g}$ for $5 \mathrm{~min}$ and washed with an additional $2 \mathrm{ml}$ of AIB-PBS. The cells were then diluted in $0.5 \mathrm{ml}$ of distilled water, sonicated, and quantitatively transferred to counting vials with $10 \mathrm{ml}$ scintillation fluid and assayed.

Lysosomal enzyme release. PMNL were prepared as previously outlined $(23)$, and $0.3 \mathrm{ml}$ of $16.6 \times 10^{6} / \mathrm{ml}$ pipetted into $13 \times 100-\mathrm{mm}$ glass tubes containing 0.05 or $0.1 \mathrm{ml}$ of the diluted alcohol and (or) zymosan particles which had been previously treated with normal human serum (boiled and extensively washed zymosan which was treated for $30 \mathrm{~min}$ at $37^{\circ} \mathrm{C}$ with human $\mathrm{AB}^{+}$serum [Z-NHS]) $(34,35)$. Most studies were performed at a particle-cell ratio of 40 , because in preliminary studies, this ratio produced near maximal release. After the PMNL were challenged with Z-NHS (20 min in most experiments), cells were pelleted, and the supernate was removed. The cell pellet was analyzed for cAMP as previously described. $\beta$-Glucuronidase activity was determined in a $0.05-\mathrm{ml}$ aliquot by a standard method in which the supernates were incubated in the presence of $0.15 \mathrm{ml}$ of sodium acetate and phenolphthalein-glucuronide as substrate (34-37). After an 18 -h incubation at $37^{\circ} \mathrm{C}$, $1.25 \mathrm{ml}$ of 2-amino-2-methyl-1-propanol buffer (pH 11.0) was added, and the optical density was determined at $\mathbf{5 4 0}$ $\mathrm{nM}$. Cellular content of $\beta$-glucuronidase was similarly determined on cells which had been through eight ethanol-dry ice freeze-thaw cycles or exposed to $0.1 \%$ Triton-X-100 (Rohm \& Haas Co., Philadelphia, Pa.). These two techniques of cell disruption produced activities which were $\pm 10 \%$ of each other.

Histamine release. The analysis of the effect of alcohols on histamine release was examined by utilizing techniques previously described from this laboratory $(26,38,39)$. The cells were preincubated for $10 \mathrm{~min}$ with the alcohol, and then the releasing agent was added.

Statistical methods. The results are expressed as the mean \pm SEM. The means are compared using the Student's $t$ test, and the levels of significance are expressed as $P$ values.

\section{RESULTS}

Effect of alcohols on lymphocyte cAMP concentrations. Initially we compared the various cell types (human lymphocytes, platelets, and granulocytes and rabbit alveolar macrophages), and lymphocytes not only had the highest basal cAMP content on a per cell basis but also had by far the greatest responses to $\mathrm{PGE}_{1}$ and epinephrine (Table I). Therefore, because of their relatively high basal levels, marked measurable responses to various stimulants with respect to cAMP metabolism, availability in large numbers, and ease of purification, lymphocytes were selected for our initial studies of the effects of alcohols on leukocyte cAMP metabolism. The effects of ethanol on lymphocyte cAMP concentrations are presented in Fig. 1. Dose-related increases in cAMP were obtained at ethanol concentrations from 0.10 to $5 \%$ ( $\mathrm{vol} / \mathrm{vol})$. The kinetics of the cAMP response to ethanol are depicted in Fig. 2. The response occurred during the initial $10 \mathrm{~min}$ with particularly marked increases during the first 2 min. Although cAMP levels were maximally elevated early, the concentrations remained elevated up to at least $60 \mathrm{~min}$. Three other alcohols, 1-butyl, 1-amyl, and phenethyl (also shown in Fig. 2), produced larger changes which occurred over a similar time-course. Similar cAMP elevations were observed in $\mathrm{T}$ lymphocytes and in mixed lymphocytes incubated in $10 \%$ (vol/vol) $\mathrm{AB}^{+}$serum. The same cAMP alterations were also obtained in tissue extracts measured directly or subjected to chromatographic purification before radioimmunoassay. The ethanol concentrations employed in Table II and Figs. 1 and 2 did not alter extracellular $\mathrm{pH}$ more than $0.1 \mathrm{U}$, were not cytotoxic as judged by the ability of the cells to exclude trypan blue at the end of the incubation period, and did not produce effects through changes in osmolarity inasmuch as equimolar concentrations of glucose had no effect on intracellular cAMP levels. In contrast to cAMP, no significant changes in cGMP concentrations were observed.

To evaluate the influence of the carbon skeleton of alcohols on the cAMP response in lymphocytes, a number of short-chain aryl and aliphatic alcohols were compared over a broad dose range (Fig. 3). At high concentrations, all alcohols tested were cytotoxic as demonstrated both by the failure of the cells to exclude trypan blue and reduction (with respect to maximal) of cAMP levels. Alcohols giving a less than twofold increase in cAMP at any concentration included methyl, isopropyl, and tertiary-butyl. 1-pro- 
TABLE I

cAMP Concentrations in Resting and Stimulated Cells Involved in the Inflammatory and (or) Immune Response*

\begin{tabular}{|c|c|c|c|c|c|c|}
\hline & $\begin{array}{l}\mathrm{pmol} / 10^{\tau} \text { cells } \\
\text { Basal levels }\end{array}$ & \multicolumn{5}{|c|}{ Stimulation ratio } \\
\hline Mixed lymphocytes & $24.2 \pm 2.2$ & $19.9 \pm 5.3$ & $4.2 \pm 1.4$ & $2.8 \pm 0.5$ & $23.9 \pm 5.9$ & $5.1 \pm 0.6$ \\
\hline T lymphocytes & $7.5 \pm 2.0$ & $22.8 \pm 6.4$ & $2.9 \pm 1.7$ & $2.1 \pm 0.4$ & $21.0 \pm 2.5$ & $10.2 \pm 3.3$ \\
\hline Granulocytes $\S$ & $3.0 \pm 0.7$ & $2.4 \pm 0.6$ & $1.0 \pm 0.1$ & $1.4 \pm 0.2$ & $9.3 \pm 1.8$ & $2.9 \pm 0.4$ \\
\hline
\end{tabular}

* The lymphocytes, granulocytes, and platelets were obtained from the peripheral blood of normal human donors. Methods employed to extract and measure cAMP were identical for each cell type (see Methods). The stimulation ratio in this and subsequent tables and figures represents cAMP concentrations after exposure to the stimulatory agents divided by the control values. These data points represent the mean \pm SEM for at least four experiments at each point and were determined 10 min after the addition of the stimulatory agents: $\mathrm{PGE}_{1}$, epinephrine (Epi), and theophylline (Theo). Similar data for rat peritoneal mast cells can be found in reference (26).

\$ Theophylline-treated lymphocytes were used in the denominator in calculating the stimulation ratio.

$\S$ In contrast to the other cell types shown here, the basal cAMP concentration in granulocytes was $16.1 \pm 4$ when cAMP was purified prior to assay by perchloric acid precipitation and ion-exchange chromatography (see Methods). However, the stimulation ratios were similar by either method.

panol, 1-butanol, and 1-amyl consistently produced more marked responses than their corresponding isoderivatives. The responses to benzyl and phenethyl alcohol are of special interest because the former is often included as a preservative in heparin preparations $(3,40)$, whereas the latter has been considered to be a selective membrane perturbing agent with inhibitory effects on cell growth similar to those of exogenous cAMP (41).

When extracts from lymphocytes exposed to various alcohols were incubated with cyclic nucleotide PDE, inhibitory activity in the cAMP immunoassay was reduced to $<10 \%$ of the original value. With tissue extracts from 1-butanol-stimulated lymphocytes, the loss of immunoreactivity was found to be dependent on the concentration of PDE and time of incubation. The ethanol induced immunoreactivity also cochromatographs with cAMP in an isobutyric acid$\mathrm{NH}_{4} \mathrm{OH}-\mathrm{H}_{2} \mathrm{O}(66: 1: 33)$ solvent system. These studies were necessary because of a recent report that in broken rat fat cells certain alcohols form adducts with adenosine during adenylate cyclase measurements (42).

Effect of selected alcohols on cAMP metabolism in cells involved in the inflammatory response. The effects of ethanol and other selected alcohols on cAMP concentrations were examined in three additional cell types, human PMNL and platelets, and rabbit alveolar macrophages. These cell types were selected because of their importance in inflammatory and immunological processes. In accord with results with agents such as $\mathrm{PGE}_{1}$ and epinephrine (Table I), only modest cAMP responses were obtained in the absence of a PDE inhibition. However, with theophyl- line present, (Table II, shown at alcohol concentrations giving a maximum response at $10 \mathrm{~min}$ in these (ell types), the dose dependency and kinetics of the responses could be measured in these cell types. Kinetic studies demonstrated a similar, although somewhat more prolonged, time-course by comparison with that seen in lymphocytes.

Effect of alcohols on lymphocyte PDE and adenylate cyclase activity. At concentrations which stimulated cAMP metabolism, ethyl, 1-butyl, amyl, benzyl, and phenethyl alcohol did not inhibit either the high (50 $\mu \mathrm{M})$ or low $(2 \mu \mathrm{M}) K_{m}$ lymphocyte PDE. In these same experiments theophylline produced 76 and $45 \%$ inhibition of PDE activity at 5 and $0.5 \mathrm{mM}$, respectively.

These observations suggest that the various alcohols were directly stimulating adenylate cyclase activity in human lymphocytes. Examination of this possibility in lymphocyte membrane preparations is hindered because adenylate cyclase activity is unstable and certain activities (e.g. epinephrine responsiveness) are lost when the cells are disrupted despite retention of fluoride and $\mathrm{PGE}_{1}$ stimulatory activity $(32,33)$. Nonetheless, in a series of experiments, ethanol stimulated adenylate cyclase activity at concentrations which produced elevations of cAMP in whole cells (Table III). Definite stimulatory activity was also found at the same concentrations of several additional alcohols which stimulate cAMP accumulation in intact cells, although as with ethanol, the stimulation ratio was not as large as in intact cells.

DNA synthesis. The effect of ethanol and other alcohols on DNA synthetic responses to PHA, Con A, and antithymocyte globulin were evaluated under a 


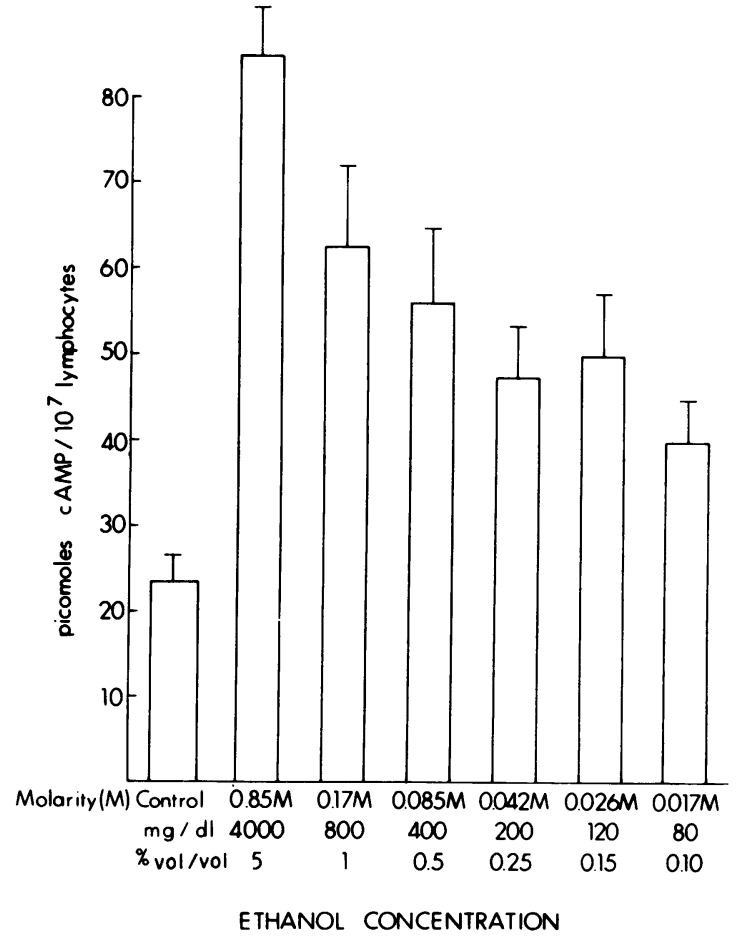

FIGURE 1 cAMP concentrations in human peripheral blood lymphocytes exposed to ethanol. These values were determined after a 10-min exposure to ethanol and represent the mean $\pm S E M$ for eight experiments at each point (except for the $0.15 \%$ concentration which is the mean $\pm S E M$ for four experiments). At each ethanol concentration shown, the levels were significantly $(P<0.05)$ greater than control. At $0.05 \%(\mathrm{vol} / \mathrm{vol})$ the mean cAMP concentration was 28 compared to a control mean value of $24 \mathrm{pmol} / 10^{7}$ cells, but this difference is not statistically significant. The ethanol concentrations on the ordinate are presented in molarity, milligrams per deciliter, and percent (volume ratio) in order that the reader can easily convert the data in the text and other graphic material to the form with which he is most familiar.

variety of stimulatory conditions. These experiments produced different results depending upon the mitogen, alcohol, and their respective concentrations. The most extensive studies were with E-PHA. Ethanol produced significant inhibition of transformation only at the highest concentrations, 1 and $0.5 \%$, and then only at nonoptimal mitogenic concentrations of E-PHA $(50,25$, and $10 \mu \mathrm{g} / \mathrm{ml})$. Responses to Con $\mathrm{A}(25,10$, and $5 \mu \mathrm{g} / \mathrm{ml})$ and antithymocyte globulin (250 and $125 \mu \mathrm{g} / \mathrm{ml}$ ) were not inhibited under any condition. Two other aliphatic alcohols, 1-butanol and 1-pentanol, which produce large increases in lymphocyte cAMP were also studied. Neither alcohol inhibited the DNA synthetic response to optimal concentrations of E-PHA ( 5 and $1 \mu \mathrm{g} / \mathrm{ml}$ ). In contrast, the aryl alcohols, phenethyl and benzyl, produced a dose-dependent inhibition of E-PHA-stimulated uptake of $\left[{ }^{3} \mathrm{H}\right]$ thymidine (Table IV). For example, at 5

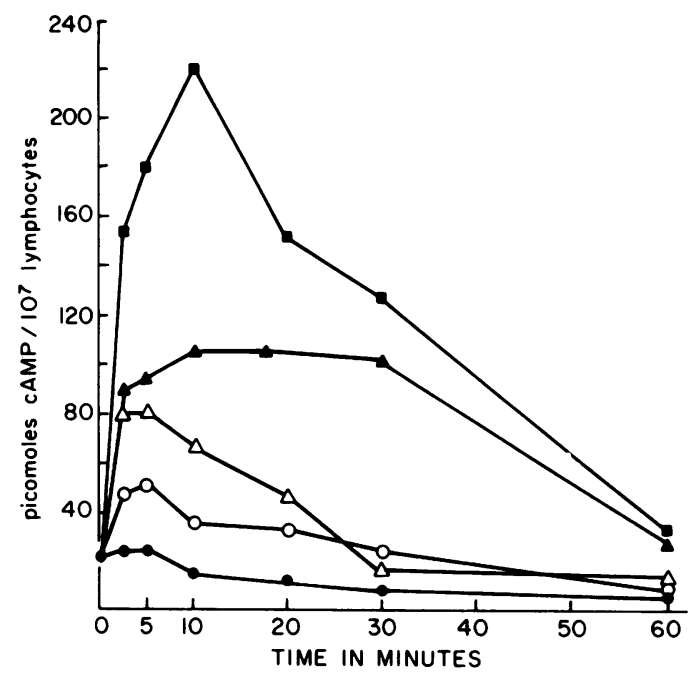

FIGURE 2 Kinetic analysis of the cAMP response to selected alcohols. This representative study was performed in triplicate ( $<10 \%$ intertube variation) on a single donor's lymphocytes. - Control; $\bigcirc$, ethanol $(0.5 \%) ; \Delta$, phenethyl alcohol $(0.25 \%) ; \Delta, \quad$-butanol, $(0.5 \%)$; and $\boldsymbol{\square}, n$-amyl alcohol $(0.5 \%)$.

and $1 \mu \mathrm{g} / \mathrm{ml}$ E-PHA, phenethyl alcohol produced a $>75 \%$ reduction in thymidine incorporation at 0.05 and $0.025 \% \mathrm{vol} / \mathrm{vol}$.

$A I B$ transport. Because thymidine incorporation is the end result of a complex series of metabolic events and because of the controversy surrounding the role of cAMP in lymphocyte activation (43), we also examined the effects of alcohols on transport of nonmetabolizable amino acid analogue AIB. Augmentation of sodium-dependent amino acid transport

TABLE II

Effect of Alcohols on cAMP Concentrations in Human Granulocytes, Rabbit Alveolar Macrophages, and Human Platelets*

\begin{tabular}{lcccc}
\hline & & \multicolumn{3}{c}{ Stimulation ratio } \\
\cline { 3 - 5 } Alcohols & $\begin{array}{c}\text { Volume } \\
\text { ratio }\end{array}$ & $\begin{array}{c}\text { Human } \\
\text { granulocytes }\end{array}$ & $\begin{array}{c}\text { Rabbit } \\
\text { alveolar } \\
\text { macrophages }\end{array}$ & $\begin{array}{c}\text { Human } \\
\text { platelets }\end{array}$ \\
\hline & $\%$ & & & \\
Ethyl & 1.0 & $1.3 \pm 0.1$ & $1.5 \pm 0.2$ & $1.2 \pm 0.1$ \\
1-Butyl & 0.5 & $1.8 \pm 0.3$ & $2.5 \pm 0.1$ & $1.4 \pm 0.2$ \\
Amyl & 0.5 & $2.2 \pm 0.1$ & $2.4 \pm 0.3$ & $1.6 \pm 0.4$ \\
Phenethyl & 0.25 & $1.5 \pm 0.2$ & $1.4 \pm 0.2$ & $1.2 \pm 0.3$ \\
\hline
\end{tabular}

* These studies were performed in the presence of $5 \mathrm{mM}$ theophylline. The data represent the mean \pm SEM for at least four experiments performed in triplicate in which the cAMP concentration was determined $10 \mathrm{~min}$ after the addition of alcohol. The stimulation ratios are significantly different $(P<0.05)$ from the control except for those in platelets in response to ethyl and phenethyl alcohol. 


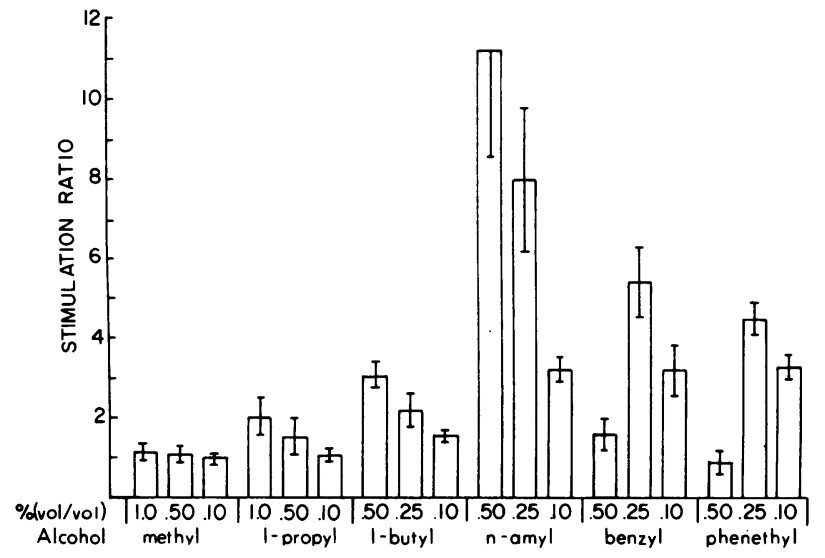

FIGURE 3 Comparison of the cAMP stimulatory capacity of selected short-chain aryl and aliphatic alcohols. These values were obtained after a 10 -min exposure to the alcohol and represent the mean $\pm S E M$ for at least three experiments at each point. The stimulation ratio represents the cAMP concentrations in alcohol-treated cells divided by control levels which had a basal concentration of 24.8 $\pm 4.1 \mathrm{pmol} \mathrm{cAMP} / 10^{7}$ cells. Higher concentrations of 1-butyl, $n$-amyl, benzyl, and phenethyl alcohol were cytotoxic, as evidenced by the failure to exclude trypan blue and decreased cAMP concentrations. is one of the early alterations of lymphocytes eventually to undergo transformation $(43,44)$. In the present studies, ethanol inhibited AIB transport only at the $5.0 \%$ concentration (Table V). A number of other aliphatic and aryl alcohols did produce inhibition at considerably lower concentrations in approximate relation to their ability to raise lymphocyte cAMP concentrations. At high alcohol concentrations on a percentage basis, basal and mitogen-stimulated AIB uptake was inhibited to the same extent. At lower concentrations, basal AIB uptake appeared to be more susceptible to inhibition. Cell viability was $>90 \%$ in all cases. It is of interest that 1-butanol was able to inhibit AIB transport at concentrations which did not alter mitogenesis.

Lysosomal enzyme release. Ethanol produced dose-dependent inhibition of the release of $\beta$-glucuronidase (Table VI). Methanol, a nonstimulator of cAMP accumulation, did not inhibit lysosomal enzyme release, but a large number of other short-chain aliphatic and aryl alcohols including isopropyl, $n$-, sec-, tert-, and isobutyl, $n$ - and isoamyl, benzyl, and phenethyl caused dose-dependent inhibition. The inhibition was not secondary to nonspecific cytotoxicity because in all cases $>90 \%$ of PMNL excluded trypan blue at the end of the phagocytic studies. The inhibitory effect could also be secondary

TABLE III

Effect of Alcohols on Adenylate Cyclase in Human Lymphocyte Subcellular Fractions*

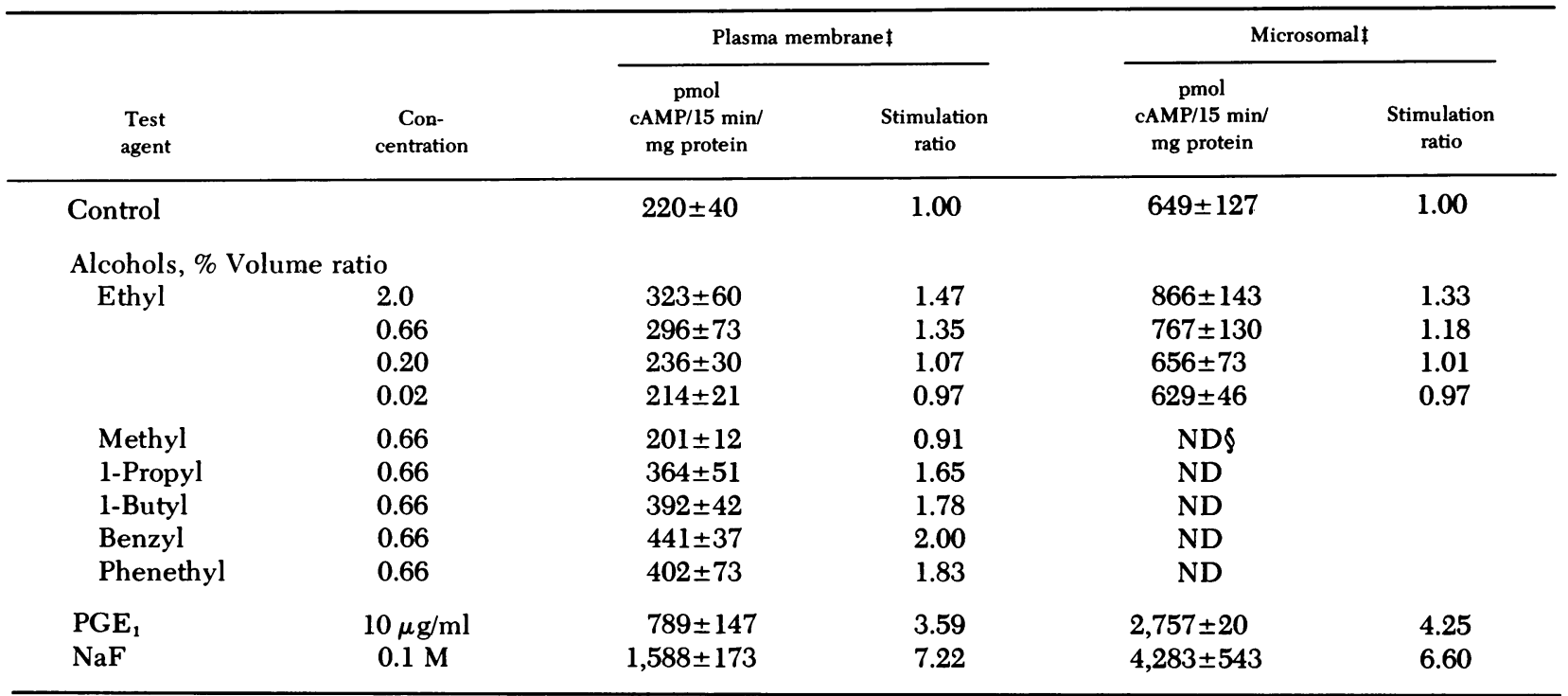

* These data represent the mean \pm SEM of four and two experiments performed in triplicate for ethanol and the other alcohols, respectively. In three of four ethanol experiments, studies were done with and without GTP (0.05 $\mathrm{mM})$ in the incubation media. GTP augmented basal activity of adenylate cyclase in both fractions as well as the ethanol-induced increase in activity. However, the stimulation ratios were similar with or without GTP. The data for both fractions are significantly different at the 0.05 level for ethyl $(2.0 \%)$ and for all the other alcohols except methyl. At $0.66 \%$ ethanol, the $P$ value is $<0.1$ but $>0.05$. \$ The enzymatic and microscopic characterization of these fractions and their method of preparation have been published (32). $\S$ Not done. 
TABLE IV

Effect of Alcohols on Lymphocyte Mitogenesis*

\begin{tabular}{|c|c|c|c|c|c|c|}
\hline & \multirow[b]{2}{*}{ Volume ratio } & \multirow[b]{2}{*}{ Control } & \multicolumn{4}{|c|}{ Stimulation ratio E-PHA } \\
\hline & & & 25 & 10 & 5 & 1 \\
\hline & $\%$ & & \multicolumn{4}{|c|}{$\mu g / m l$} \\
\hline \multirow[t]{3}{*}{ Phenethyl alcohol } & 0.05 & $0.6 \pm 0.3$ & $0.4 \pm 0.3 \ddagger$ & $0.6 \pm 0.2 \ddagger$ & $2.2 \pm 0.3 \ddagger$ & $21.3 \pm 1.1 \neq$ \\
\hline & 0.025 & $1.0 \pm 0.6$ & $1.3 \pm 0.2$ & $7.8 \pm 2.9$ & $8.3 \pm 4.3 \ddagger$ & $42.8 \pm 4.5 \ddagger$ \\
\hline & 0.01 & $0.8 \pm 0.3$ & $5.7 \pm 1.7 \S$ & $15.9 \pm 1.8$ & $16.3 \pm 2.4 \ddagger$ & $48.0 \pm 4.1 \ddagger$ \\
\hline Cells alone & & 1.0 & $1.7 \pm 0.3$ & $13.3 \pm 1.4$ & $36.7 \pm 4.9$ & $75.2 \pm 2.1$ \\
\hline
\end{tabular}

* These data represent the mean \pm SEM for four experiments ( 12 separate conditions) at each point. Thymidine incorporation was determined at $72 \mathrm{~h}$. Similar data were obtained in an additional experiment in which thymidine incorporation was determined at $48 \mathrm{~h}$. Lymphocyte viability (trypan blue exclusion) was $55-65 \%$ at $72 \mathrm{~h}$ in both control and alcohol-treated conditions. Higher alcohol concentrations produced more marked inhibition, but there was decreased viability. Similar data to that shown with phenethyl alcohol was obtained with benzyl alcohol.

f Stimulation ratio significantly $(P<0.05)$ less than the corresponding cell plus mitogen control.

$\S$ Stimulation ratio significantly $(P<0.05)$ greater than the corresponding cell plus mitogen control. Modest stimulation was also observed with other alcohols, but only at low concentrations and at nonoptimal mitogen concentrations.

to the alcohols directly inhibiting $\beta$-glucuronidase activity. This possibility was examined by testing low (1 $\mu \mathrm{g}$ phenolphthalein/18 $\mathrm{h}$ per $1 \times 10^{6} \mathrm{PMNL}$ ), moderate $(10 \mu \mathrm{g})$, and high $(25 \mu \mathrm{g})$ enzymatic activity. Only benzyl and isoamyl alcohol, of the ones listed above, inhibited enzymatic activity per se so these alcohols were not employed in studies of lysosomal enzyme release.

The possibility was also considered that ethanol was preventing the attachment or ingestion phases of phagocytosis such that the inhibition of lysosomal enzyme release was only a secondary phenomenon. To block the ingestion phase of phagocytosis, PMNL were treated with cytochalasin B $(5 \mu \mathrm{g} / \mathrm{ml})$ for $10 \mathrm{~min}$ before the addition of the zymosan particles. In this system, ethanol inhibited lysosomal enzyme secretion at least as much as, and in some cases, more than when cytochalasin B was absent (data not shown). The data suggest, therefore, that ethanol is modulating enzyme release rather than the attachment or ingestion phases of phagocytosis.

Histamine release from rat mast cells. Mast cells were incubated in the presence of ethanol, phenethyl alcohol, amyl alcohol, or medium alone as a control for $10 \mathrm{~min}$ at $37^{\circ} \mathrm{C}$. The cells were then stimulated by the addition of goat anti-rat-IgE or the calcium ionophore A-23187, and the incubation continued for 15 min. The amount of histamine released into the medium and the amount remaining in the cell pellet were determined by fluorometric assay (34). As summarized in Table VII, ethanol inhibited mediator release induced by anti-IgE or A-23187 with $50 \%$ inhibition occurring at 0.39 and $0.26 \%$ ethanol, respectively. Phenethyl and amyl alcohol also inhibited anti-IgE-induced release with $50 \%$ inhibition noted at 0.10 and $0.18 \%$, respectively (data not shown).
Ethanol was also tested with Con A (100 $\mu \mathrm{g} / \mathrm{ml})$ as the releasing stimulus and again inhibition was noted ( $50 \%$ inhibition at $0.28 \%$ ethanol-data not shown). After we established that ethyl, amyl, and phenethyl alcohols were potent inhibitors of mediator release induced by diverse stimuli, we probed the mechanism of this action by examining the effects of these alcohols on mast cell cAMP. In three experiments unstimulated control cAMP was $28.2 \pm 8.6 \mathrm{pmol} / \mathrm{million}$ mast cells. A 10-min incubation of 0.15 million cells in $0.50 \mathrm{ml}$ at $37^{\circ} \mathrm{C}$ in the presence of $0.2 \%$ ethyl, phenethyl, or amyl alcohols resulted in cAMP levels $102 \pm 4.5$ SEM, $95.7 \pm 12.0$, and $89.7 \pm 8.0 \%$ of control values. Thus, under conditions resulting in marked suppression of mediator release, no change in mast cell cAMP levels was observed.

\section{DISCUSSION}

In the present report ethanol has been shown to inhibit lysosomal enzyme release from phagocytosing human PMNL and histamine release from rat mast cells induced by both immunologic (anti-IgE) and nonimmunologic stimuli (A-23187 and Con A). These effects were seen over a broad range of ethanol concentrations including levels associated with moderate to severe inebriation in humans. Several other aryl and alkyl alcohols were shown to be even more potent inhibitors of these processes suggesting that the hydroxyl itself is somehow involved in the inhibition.

The results with cytochalasin B make it likely that the ethanol effect is directly on lysosomal enzyme secretion rather than the attachment and ingestion phases of phagocytosis. In one previous study in human neutrophils, no effect of alcohol on lysosomal enzyme release was seen, but considerably longer 
TABLE V

Effect of Alcohols on $\left[{ }^{14} \mathrm{C}\right] A I B$ Transport in Human Lymphocytes*

\begin{tabular}{lccc}
\hline & & \multicolumn{2}{c}{ Stimulation ratio } \\
\cline { 3 - 4 } Condition & $\begin{array}{c}\text { Con- } \\
\text { centration }\end{array}$ & Cells & $\begin{array}{c}\text { Cells } \\
+ \text { Con A } \\
(25 \mu \mathrm{g} / \mathrm{ml})\end{array}$ \\
\hline Control & & 1.00 & $1.64 \pm 0.13$ \\
Alcohols, \% & Volume ratio & & \\
Ethyl & 5.0 & $0.55 \pm 0.11$ & $0.46 \pm 0.14$ \\
& 1.0 & $1.25 \pm 0.13$ & $1.71 \pm 0.34$ \\
& 0.5 & $1.21 \pm 0.16$ & $1.66 \pm 0.28$ \\
& 0.25 & $1.04 \pm 0.02$ & $1.57 \pm 0.18$ \\
1-Butyl & 0.10 & $0.91 \pm 0.09$ & $1.35 \pm 0.22$ \\
& 0.5 & $0.39 \pm 0.07$ & $0.45 \pm 0.10$ \\
$n$-Amyl & 0.10 & $0.73 \pm 0.06$ & $1.19 \pm 0.21$ \\
& 0.05 & $0.82 \pm 0.06$ & $2.22 \pm 1.00$ \\
Benzyl & 0.5 & $0.23 \pm 0.06$ & $0.36 \pm 0.08$ \\
& 0.10 & $0.65 \pm 0.13$ & $0.99 \pm 0.06$ \\
& 0.05 & $0.87 \pm 0.26$ & $1.28 \pm 0.34$ \\
Phenethyl & 0.25 & $0.44 \pm 0.11$ & $1.00 \pm 0.03$ \\
& 0.10 & $0.55 \pm 0.09$ & $1.29 \pm 0.16$ \\
& 0.05 & $0.93 \pm 0.14$ & $1.89 \pm 0.21$ \\
Theophylline & 0.25 & $0.18 \pm 0.01$ & $0.34 \pm 0.05$ \\
PGE & 0.10 & $0.56 \pm 0.08$ & $0.81 \pm 0.07$ \\
& 0.05 & $0.71 \pm 0.20$ & $1.50 \pm 0.19$ \\
& $5 \mathrm{mM}$ & $0.55 \pm 0.13$ & $1.08 \pm 0.10$ \\
& $100 \mu \mathrm{g} / \mathrm{ml}$ & $0.68 \pm 0.04$ & $1.06 \pm 0.17$ \\
\hline & & &
\end{tabular}

* These data represent the mean \pm SEM for five experiments with ethanol and three each with the other compounds. The stimulation ratio equals $\left[{ }^{14} \mathrm{C}\right] \mathrm{AIB}$ in lectin-stimulated divided by $\left[{ }^{14} \mathrm{C}\right] \mathrm{AIB}$ cells. The counts per minute of $\left[{ }^{14} \mathrm{C}\right] \mathrm{AIB}$ obtained after a 240-h incubation of the cells or the cells + Con A were $1,679 \pm 336$ and $2,831 \pm 443$, respectively. Significant inhibition $(P<0.05)$ was present at $5.0 \%$ ethanol, at the two higher concentrations of the other alcohols, and with theophylline and $\mathrm{PGE}_{1}$.

incubation times, different particle-to-cell ratios, and $10 \%$ serum were used which may have masked important effects of alcohol on the release mechanism (36).

While it must be kept in mind that these alcohol effects on neutrophil and mast cell function have not yet been demonstrated in vivo, it is interesting to speculate as to how host resistance to infection might be affected by the inhibition. One of the most common infections in chronic alcoholism is acute bacterial pneumonia. The studies of Wood and his colleagues clearly indicate that neutrophils are importantly involved as a first line of defense against pneumococcal infection (45). Mast cells also are prominently represented in lung and may play a similar role in defense against infection, particularly in a situation where $\operatorname{IgE}$ antibodies already have been formed. Any defects in the release of granular contents from these cells in the mounting of an inflammatory response would be superimposed on previously described inhibition of neutrophil chemotaxis $(12,13)$ and adherence (15) induced by ethanol.

In contrast to the clear-cut inhibitory effects of ethanol and other alcohols on inflammatory mediator release, the ability of these agents to alter human lymphocyte stimulation by lectins and anti-thymocyte globulins was variable. In a previous study ethanol concentrations of 100,200 , and $300 \mathrm{mg} / 100 \mathrm{ml}$ produced a dose-dependent inhibition of PHA-induced lymphocyte transformation (16), but another group using equally high concentrations of ethanol with PHA failed to demonstrate inhibition (46). In the present report ethyl and other aliphatic alcohols inhibited thymidine uptake and AIB transport only at the highest concentrations examined, and then only when suboptimal mitogen concentrations were

TABLE VI

Effect of Alcohols on the Zymosan-Stimulated Release of Lysosomal Enzymes from Human Granulocytes*

\begin{tabular}{|c|c|c|c|}
\hline & Volume ratio & $\begin{array}{l}\beta \text {-Glucuronidase } \\
\text { activity released } \\
\text { into supernate }\end{array}$ & $\begin{array}{l}\text { Inhibition } \\
\text { of release }\end{array}$ \\
\hline & $\%$ & $\%$ & $\%$ \\
\hline $\begin{array}{l}\text { Alcohols, } \\
\text { Ethyl }\end{array}$ & $\begin{array}{l}5.0 \\
1.0 \\
0.5 \\
0.3 \\
0.15 \\
0.075 \\
0.025\end{array}$ & $\begin{array}{r}9.5 \pm 1.6 \ddagger \\
12.5 \pm 1.4 \ddagger \\
16.9 \pm 1.3 \ddagger \\
18.1 \pm 0.9 \ddagger \\
19.1 \pm 1.2 \ddagger \\
22.4 \pm 1.3 \\
23.6 \pm 2.6\end{array}$ & $\begin{array}{r}87 \\
70 \\
45 \\
39 \\
32 \\
13 \\
6\end{array}$ \\
\hline 1-Butyl & $\begin{array}{l}0.5 \\
0.3 \\
0.1\end{array}$ & $\begin{array}{r}8.5 \pm 0.5 \ddagger \\
13.0 \pm 1.0 \ddagger \\
20.2 \pm 2.1\end{array}$ & $\begin{array}{l}93 \\
67 \\
25\end{array}$ \\
\hline Phenethyl & $\begin{array}{l}0.2 \\
0.1 \\
0.05 \\
0.01\end{array}$ & $\begin{array}{l}10.7 \pm 0.7 \ddagger \\
14.9 \pm 1.0 \ddagger \\
18.0 \pm 1.0 \ddagger \\
28.9 \pm 2.7\end{array}$ & $\begin{array}{r}80 \\
66 \\
38 \\
-24\end{array}$ \\
\hline Cells + Z-NHS & & $24.6 \pm 1.5$ & \\
\hline Cells alone & & $7.3 \pm 1.2$ & \\
\hline
\end{tabular}

* These data represent the mean \pm SEM of 10 experiments for ethanol and three experiments each for phenethyl and 1-butyl. Marked dose-dependent inhibition at noncytotoxic concentrations of a variety of additional alcohols was also observed (see text). The value for total cell $\beta$-glucuronidase activity was $22.3 \pm 1.6 \mu \mathrm{g}$ phenolphthalein/18 $\mathrm{h}$ per $1 \times 10^{8}$ PMNL.

† Significantly different $(P<0.05)$ compared to cells and Z-NHS. 
TABLE VII

Effect of Ethanol on Histamine Release from Rat Mast Cells

\begin{tabular}{ccc}
\hline Addition & $\begin{array}{c}\text { Net histamine } \\
\text { release* }\end{array}$ & Inhibition \\
\hline & $\%$ & $\%$ \\
Anti-IgE $(1: 250) \neq$ & $27.0 \pm 5.8$ & \\
+ 0.1\% Ethanol & $18.1 \pm 4.2$ & 33.0 \\
+ 0.5\% Ethanol & $11.8 \pm 3.2$ & 56.3 \\
A-23187 (0.1 $\mu \mathrm{g} / \mathrm{ml})$ & $40.4 \pm 10.4$ & \\
+ 0.1\% Ethanol & $29.2 \pm 3.4$ & 27.7 \\
+ 0.5\% Ethanol & $6.9 \pm 4.2$ & 82.9 \\
\hline
\end{tabular}

* Spontaneous release of histamine averaged $5.7 \%$.

$\$$ Mast cells $\left(1.5 \times 10^{5}\right)$ were preincubated in $0.50 \mathrm{ml}$ of medium containing ethanol or medium alone as a control for $10 \mathrm{~min}$ at $37^{\circ} \mathrm{C}$. After the addition of releasing agents $(0.05 \mathrm{ml})$, the cells were incubated an additional $15 \mathrm{~min}$. Data presented as mean $\pm S E M$ of results in five experiments.

employed. In contrast, the aryl alcohols inhibited both these processes over a wide concentration range and at optimal mitogenic levels.

One of the most important observations of the present study was that short-chain aliphatic and aryl alcohols were found to elevate intracellular cAMP concentrations in a number of the cells which have a vital role in inflammatory and immunity including PMNL, platelets, macrophages, and especially lymphocytes. In broken lymphocyte preparations, alcohols increased the activity of the enzyme which synthesizes cAMP, adenylate cyclase, whereas no effect was observed on cAMP PDE which is responsible for cAMP breakdown. It therefore appears likely that the effect of alcohols in the intact cells is through cAMP formation rather than through inhibitory effects on cAMP catabolism. In support of this possibility, stimulatory effects of ethanol on adenylate cyclase have been described in other tissues $(4-9,47)$.

Initially, we were surprised to find that alcohols elevated cAMP concentrations in immunocompetent cells. We later demonstrated that the product was cAMP itself and not an adduct (3). We and others have used ethanol as a solvent for prostaglandins and steroids in prior studies on cAMP metabolism in leukocytes. Despite the use of appropriate controls in these studies, stimulatory effects of ethanol were not noted, probably because the final concentration of ethanol in the suspension was usually equal to or less than $0.1 \%$, the response to the pharmacological stimulator was much greater, and sufficiently early time points were not evaluated. Moreover, in whole blood leukocytes the response might easily be missed unless a PDE inhibitor was also present.

There are at least six cellular processes important in inflammation and immunity that are known to be suppressed by increases in intracellular cAMP (reviewed in references 1, 2, and 43): (a) lysosomal enzyme release from PMNL and macrophages, $(b)$ histamine release from mast cells and basophilic leukocytes, (c) antibody-dependent, lymphocyte-mediated cytotoxicity, (d) lymphocyte activation, $(e)$ platelet aggregation, $(f)$ PMNL and macrophage motility (14), and PMNL adherence (48). In many of these studies cAMP levels were not directly measured, and the evidence that cAMP was inhibitory was based primarily on inhibitory effects of exogenous cAMP or pharmacologic agents known to promote cAMP accumulation. However, a sufficient number of direct cAMP measurements are now available to establish an antagonistic action of cAMP in most or all of these processes.

Despite the apparent anti-inflammatory action of cAMP, the role of cAMP in the modulatory effects of alcohols on lymphocyte, neutrophil, and mast cell function is uncertain. As discussed above, aryl and aliphatic alcohols have contrasting effects on lymphocyte function even though they produce similar elevations of cAMP. Moreover, the cAMP response to ethanol was minimal in PMNL, in being consistently observable only in the presence of theophylline, whereas no reproducible changes at all were seen in mast cells under conditions where there is marked inhibition of histamine release. Nonetheless, cAMP and ethanol do inhibit many of the same processes, and several of the other cAMP agonists that inhibit release reactions in neutrophils and mast cells are also relatively poor stimulators of cAMP accumulation in these cells. It may be that ethanol and cAMP are modulating these reactions through a different pathway, or that both are affecting an unknown common denominator important in cell membrane function. If functionally distinct pools of cAMP existed in the same cells, as we and others have suggested, then modest or even undetectable changes in whole cell cAMP might be associated with marked changes in cellular function $(1,42,49)$. Further studies are needed to distinguish between these possibilities.

\section{ACKNOWLEDGMENTS}

This work was supported by U. S. Public Health Service Program Project AI 12450 and Training Grant GM 00371-16, and by National Institutes of Health Fellowship AI 01721.

\section{REFERENCES}

1. Parker, C. W., T. J. Sullivan, and H. J. Wedner. 1974. Cyclic AMP and the immune response. In Advances in Cyclic Nucleotide Research, Cyclic AMP, and the Immune Response. P. Greengard and G. A. Robison, editors. Raven Press, New York. 4: 1-79.

2. Bourne, H. R., L. M. Lichtenstein, K. L. Melmon, C. S. Henney, Y. Weinstein, and G. M. Shearer. 1974. 
Modulation of inflammation and immunity by cyclic AMP. Science (Wash. D. C.). 184: 19-28.

3. Atkinson, J. P., M. C. Udey, H. J. Wedner, and C. W. Parker. 1976. Studies on the stimulation of cAMP metabolism by heparin solutions containing benzyl alcohol. J. Cyclic Nucleotide Res. 2: 297-305.

4. Greene, H. L., H. Herman, and S. Kraemer. 1971. Stimulation of jejunal adenyl cyclase by ethanol. J. Lab. Clin. Med. 78: 336-342.

5. Tague, L. L., and L. L. Shanbour. 1974. Effects of ethanol on gastric mucosal adenosine $3^{\prime}, 5^{\prime}$ monophosphate (cAMP). Life Sci. 14: 1065-1073.

6. Mashiter, K., G. Mashiter, and J. B. Field. 1974. Effects of prostaglandin E, ethanol and TSH on the adenylate cyclase activity of beef thyroid plasma membrane and cyclic AMP content of dog thyroid slices. Endocrinology. 94: 370-376.

7. Israel, M. A., H. Kimura, and K. Kuriyama. 1972. Changes in activity and hormonal sensitivity of brain adenyl cyclase following chronic ethanol administration. Experientia (Basel). 28: 1322-1323.

8. Gorman, R. E., and M. W. Bitensky. 1970. Selective activation by short chain alcohols of glucagon responsive adenyl cyclase in liver. Endocrinology. 87: 1075-1081.

9. Kuo, W. N., D. S. Hodgins, and J. F. Kuo. 1973. Adenylate cyclase in islets of langerhans. Isolation of islets and regulation of adenylate cyclase activity by various hormones and agents. J. Biol. Chem. 218: 2705-2711.

10. Austrian, R., and J. Gold. 1964. Pneumococcal bacteremia with especial reference to bacteremic pneumococcal pneumonia. Ann. Intern. Med. 60: 759-776.

11. Pickrell, K. L. 1938. The effect of alcoholic intoxication and ether anesthesia on resistance to pneumococcal infection. Bull. Johns Hopkins Hosp. 63: 238-260.

12. Brayton, R. G., P. E. Stokes, and M. S. Schwartz. 1970. Effect of alcohol and various diseases on leukocyte mobilization, phagocytosis, and intracellular bacterial killing. N. Engl. J. Med. 282: 123-128.

13. Spagnuolo, P. J., and R. R. MacGregor. 1975. Acute ethanol effect on chemotaxis and other components of host defense. J. Lab. Clin. Med. 86: 24-31.

14. Pick, E. 1972. Cyclic AMP affects macrophage migration. Nat. New Biol. 238: 176-177.

15. MacGregor, R., P. Spagnuolo, and A. Lentnek. 1974. Inhibition of granulocyte adherence by ethanol, prednisone and aspirin. Measure with an assay system. N. Engl. J. Med. 291: 642-646.

16. Tixman, G., and V. Herbert. 1973. In vitro myelosuppression and immunosuppression by ethanol. J. Clin. Invest. 52: 1410-1414.

17. Smith, J. W., A. L. Steiner, W. M. Newberry, and C. W. Parker. 1971. Cyclic adenosine $3^{\prime}, 5^{\prime}$ monophosphate in human lymphocytes. Alterations after phytohemagglutinin stimulation. J. Clin. Invest. 50: 432-441.

18. Smith, J., A. L. Steiner, and C. W. Parker. 1971. Human lymphocyte metabolism. Effects of cyclic and noncyclic nucleotides on stimulation by phytohemagglutinin. $J$. Clin. Invest. 50: 442-448.

19. Parker, C. W., and J. W. Smith. 1974. Alterations in cyclic AMP metabolism in human bronchial asthma. I. Leukocyte responsiveness to $\beta$-adrenergic agents.J. Clin. Invest. 52: 48-59.

20. Wedner, H. J., R. Dankner, and C. W. Parker. 1975. Cyclic GMP and lectin induced lymphocyte activation. J. Immunol. 115: 1682-1687.

21. Eisen, S. A., H. J. Wedner, and C. W. Parker. 1972. Isolation of pure human peripheral blood T-lymphocytes using nylon wool columns. Immunol. Commun. 1: 571577.

22. Atkinson, J. P., H. J. Wedner, and C. W. Parker. 1975. Two novel stimuli of cAMP in human lymphocytes. $J$. Immunol. 115: 1023-1027.

23. Atkinson, J. P., W. C. Greene, T. A. McNearney, and C. W. Parker. 1976. Studies on the stimulation of cAMP metabolism in human lymphocytes by latex polymers. Exp. Cell Res. 99: 395-407.

24. Baenziger, N. L., and P. W. Majerus. 1974. The isolation of platelets and platelet plasma membranes. Methods Enzymol. 31: 149-155.

25. Reynolds, H. Y., J. P. Atkinson, H. H. Newball, and M. M. Frank. 1975. Receptors for immunoglobulin and complement on human alveolar macrophages. $J$. Immunol. 114: 1813-1817.

26. Sullivan, T. J., K. L. Parker, W. Stenson, and C. W. Parker. 1975. Modulation of cyclic AMP in purified rat mast cells. I. Response to pharmacologic, metabolic and physical stimuli.J. Immunol. 114: 1473-1479.

27. Steiner, A. L., D. M. Kipnis, R. Utiger, and C. W. Parker. 1969. Radioimmunoassay for measurement of adenosine 3',5' cyclic monophosphate. Proc. Natl. Acad. Sci. U.S. A. 64: $367-373$.

28. Steiner, A. L., C. W. Parker, and D. M. Kipnis. 1971. Radioimmunoassay for cyclic nucleotides. I. Preparation of antibodies and iodinated nucleotides. J. Biol. Chem. 247: 1106-1113.

29. Parker, C. W. 1976. Radioimmunoassay for Biologically Active Compounds. Prentice-Hall, Inc., Englewood Cliffs, N. J. 239 pp.

30. Sullivan, T. J., and C. W. Parker. 1973. Cyclic AMP phosphodiesterase activation of the histamine releasing agent, compound 48/80. Biochem. Biophys. Res. Commun. 55: 1334-1339.

31. LaGarde, A., and L. Colobert. 1972. Cyclic 3',5'-AMP phosphodiesterase of human blood lymphocytes. Biochim. Biophys. Acta. 276: 444-453.

32. Snider, D. E., and C. W. Parker. 1977. Adenylate cyclase activity in lymphocyte subcellular fractions. I. Characterization of non-nuclear adenylate cyclase. Biochem. J. 162: $473-482$.

33. Wedner, H. J., and C. W. Parker. 1977. Adenylate cyclase activity in lymphocyte subcellular fractions. II. Characterization of a nuclear adenylate cyclase. Biochem. J. 162: 483-491.

34. Weissman, G., R. B. Zurier, P. J. Spieler, and I. M. Goldstein. 1971. Mechanisms of lysosomal enzyme release from leukocytes exposed to immune complexes and other particles. J. Exp. Med. 134 (Suppl.): 149S.

35. Ignarro, L. J., T. F. Lint, and W. J. George. 1974. Hormonal control of lysosomal enzyme release from human neutrophils: Effects of autonomic agents on enzyme release, phagocytosis and cyclic nucleotide levels. J. Exp. Med. 139: 1395-1414.

36. Goldstein, I., S. Hoffstein, J. Gallin, and G. Weissman. 1973. Mechanisms of lysosomal enzyme release from human leukocytes: microtubule assembly and membrane fusion induced by a component of complement. Proc. Natl. Acad. Sci. U. S. A. 70: 2916-2920.

37. Gianetto, R., and C. DeDuve. 1955. Tissue fractionation studies. IV. Comparative study of the binding of acid phosphatase, $\beta$-glucuronidase and cathepsin by rat liver particles. Biochem. J. 59: 433-438.

38. Sullivan, T. J., K. L. Parker, S. A. Eisen, and C. W. Parker. 1975. Modulation of cyclic AMP in purified rat mast cells. II. Studies on the relationship between intra- 
cellular cyclic AMP concentrations and histamine release. J. Immunol. 114: 1480-1485.

39. Sullivan, T. J., K. L. Parker, A. Kulczycki, and C. W. Parker. 1976. Modulation of cyclic AMP in purified rat mast cells. III. Studies on the effects of concanavalin $A$ and anti-IgE on cyclic AMP concentrations during histamine release. J. Immunol. 117: 713-716.

40. Kemp, A., and G. Berke. 1973. Effects of heparin and benzyl alcohol on lymphocyte-mediated cytotoxicity in vitro. Cell. Immunol. 7: 512-515.

41. Wright, J., H. Ceri, and W. Lewis. 1973. Similar growth of Chinese hamster cells in the presence of phenethyl alcohol or dibutyryl cyclic AMP. Nat. New Biol. 244: 84-86.

42. Petrack, B., D. Ma, and F. Sheppy. 1974. Formation of a novel nucleotide by fat cell preparations containing adenylate cyclase. J. Biol. Chem. 249: 3661-3663.

43. Wedner, H. J., and C. W. Parker. 1976. Lymphocyte activation. Prog. Allergy. 20: 195-300.
44. Greene, W. C., C. M. Parker, and C. W. Parker. 1976. Opposing effects of mitogenic and nonmitogenic lectins on lymphocyte activation. Evidence that wheat germ agglutinin produces a negative signal. J. Biol. Chem. 251: 4017-4025.

45. Wood, W. B., Jr. 1951. Studies on the cellular immunology of acute bacterial infections. Harvey Lect. 47: 72-98.

46. Sorvell, M. F., and C. M. Leevy. 1972. Lymphocyte transformation and alcoholic liver injury. Gastroenterology. 63: 1020-1025.

47. Stolc, V. 1974. Restrained adenyl cyclase in human neutrophils: stimulation of cyclic adenosine $3^{\prime}, 5^{\prime}$ monophosphate formation and adenyl cyclase activity by phagocytosis and prostaglandins. Blood. 43: 743-748.

48. MacGregor, R. R. 1976. Cyclic nucleotide induction as a mechanism for modification of granulocyte adherence by plasma factors. Clin. Res. 24: 348A. (Abstr.)

49. Parker, C. W. 1976. Control of lymphocyte function. N. Engl. J. Med. 295: 1180-1186. 